\title{
ANALISIS KEMAMPUAN PENALARAN MATEMATIS SISWA SELAMA PANDEMI COVID-19 DITINJAU DARI MINAT BELAJAR SISWA
}

\author{
Oleh : \\ Christin Elisabet Sihombing1, Roslian Lubis ${ }^{2}$, Nunik Ardiana ${ }^{3}$ \\ Program Studi Pendidikan Matematika Fakultas Pendidikan MIPA \\ Institut Pendidikan Tapanuli Selatan
}

\begin{abstract}
Abstrak
Penelitian ini bertujuan untuk menganalisis kemampuan penalaran siswa serta kaitannya dengan minat belajar siswa selama pandemi covid-19. Subjek peneltian ini adalah kelas VIII3 SMP Negeri 5 Padangsidimpuan. Metode yang digunakan adalah metode kualitatif. Teknik pengumpulan data dan instrumen yang digunakan dalam penelitian ini adalah tes, angket tertutup, dan wawancara tak berstruktur. Analisis data dilakukan dengan cara reduksi data, penyajian data dan penyimpulan. Hasil penelitian menunjukkan kemampuan penalaran matematis siswa selama pandemi Covid -19 termasuk kategori rendah, 20\% kategori tinggi, $20 \%$ kategori sedang, dan $60 \%$ kategori rendah. Hasil angket menyimpulkan $60 \%$ siswa memiliki kemampuan penalaran matematika yang rendah dan minat belajar yang rendah karena tidak menyukai mata pelajaran matematika, 20\% siswa memiliki kemampuan penalaran matematika sedang dan minat belajar sedang karena mereka akan menyukai mata pelajaran matematika jika guru matematika mengajarkan mata pelajaran tersebutdengan menyenangkan, dan $20 \%$ siswa memiliki kemampuan penalaran matematis yang tinggi dan minat belajar yang tinggi karena menyukai mata pelajaran matematika dan selalu tertantang dengan soal-soal matematika.
\end{abstract}

Kata kunci : Kemampuan Penalaran, Minat Belajar, Pandemi Covid-19

\begin{abstract}
The purpose of this study is to analysis students' mathematical reasoning ability during Covid -19 pandemic in terms of student interest in learning. Subject of the research is eighth grade students of SMP Negeri 5 Padangsidimpuan. The approach of the research used qualitative. Instrument of the research used test, close questionnaire, and interview. Data analysis includes data reduction, data presentation, and taking conclusion.The result of the research showsstudents' mathematical reasoning ability during Covid -19 pandemicis low category, 20\% is high category, 20\% is enough category, and 60\% is low ability. The result of questionnaire concludes $60 \%$ students have low mathematical reasoning ability and low learning interest because don't like mathematical subject, 20\% students have average mathematical reasoning ability and average learning interest becausethey will like mathematical subject if mathematical teacher teach the subject in fun away, and $20 \%$ students have high mathematical reasoning ability and high learning interest because they like mathematical subjectand always challenged with math problems.
\end{abstract}

Keywords: Reasoning Ability, Learning Interest, Covid-19 Pandemic

\section{PENDAHULUAN}

Pendidikan merupakan salah satu faktor yang sangat penting dalam pembentukan pribadi manusia. Dengan pendidikan, manus Dengan pendidikan, manusia dapat mengasah potensi dirinya untuk mendapatkan bekal hidup di masa depan. Sejalan dengan perkembangan ilmu pengetahuan dan teknologi ( IPTEK ) pada saat ini matematika memiliki peranan penting, baik dari segi materi ataupun segi penerapannya.

Email : christinsihombing6@gmail.com 
Matematika merupakan ilmu yang diperoleh dengan bernalar, karena salah satu tujuan dari pembelajaran matematik adalah agar siswa mampu menggunakan penalaran dan pemecahannya pada pola dan sifat, melakukan manipulasi matematika dalam membuat generalisasi, menyusun bukti, atau menjelaskan gagasan dan pernyataan matematika. Menurut Erman suherman (dalam Harahap 2017:14), Matematika adalah disiplin ilmu tentang tata cara berfikir dan mengolah logika, baik secara kuantitatif maupun secara kualitatif. Pondasi dari matematika adalah penalaran. Menurut Suherman (dalam Konita 2019:612), Penalaran adalah proses berpikir yang dilakukan dengan suatu cara untuk menarik kesimpulan.

Penetapan kemampuan penalaran sebagai tujuan dan visi pembelajaran matematika merupakan sebuah bukti bahwa kemampuan penalaran sangat penting untuk dimiliki siswa dan pada dasarnya siswa dituntut berusaha sendiri untuk memecahkan masalah matematika dan dapat mengembangkan cara berpikirnya dalam menyelesaikan suatu masalah. Namun fakta di lapangan menunjukkan bahwa kebanyakan siswa tidak senang belajar matematika, sehingga dalam proses pembelajaran di kelas aktifitas siswa yang kurang, menyebabkan hasil belajar matematikanya rendah.

Selain penalaran siswa ada juga aspek lain yang penting dan patut diperhatikan dalam pembelajaran salah satunya yaitu minat belajar. Minat merupakan perasaan yang didapat karena berhubungan dengan sesuatu. Minat terhadap sesuatu merupakan hasil belajar dan cenderung mendukung aktivitas belajar. Minat belajar siswa dalam mengikuti pembelajaran merupakan sesuatu yang penting dalam kelancaran proses belajar mengajar. Siswa yang mempunyai minat belajar tinggi dalam proses pembelajaran dapat menunjang proses belajar mengajar untuk semakin baik, begitupun sebaliknya minat belajar siswa yang rendah maka kualitas pembelajaran akan menurun.

Pada tahun 2020, dunia dilanda Virus Covid-19. Virus covid ini sangat mengkhawatirkan bagi keadaan dan kesehatan manusia, terutama berdampak pada aktivitas pendidikan. Pelaksanaan pendidikan yang semula normal dilakukan langsung dan bertatap muka kini harus terhenti sementara dengan menggunakan berbagai media perantara. Dimana pada masa pandemi ini pembelajaran dilakukan secara daring (online) dengan menggunakan beberapa teknologi informasi sebagai penunjang pelaksanaan pembelajaran seperti zoom meeting, googleclassroom, dan sebagainya, tentu membutuhkan sarana dan prasarana yang memadai, seperti smartphone, laptop/computer, ketersediaan kuota/wifi, jaringan internet, dan lainnya. Namun tidak menutup kemungkinan untuk terus melaksanakan pembelajaran dengan lebih baik, sehingga pengetahuan, keterampilan dan kemampuan serta pola pikir siswa akan terus berkembang dan meningkat, terutama kemampuan bernalar siswa dalam belajar matematika, (Sugandi 2020:994).

Berdasarkan hasil wawancara pada observasi awal yang dilakukan peneliti di SMP Negeri 5 Padangsidimpuan pada tanggal 27 Januari 2021 dengan beberapa guru bidang studi matematika menyatakan bahwa kesulitan yang dihadapi siswa bermacam-macam, ada yang merasa kesulitan dalam menghitung dan ada juga yang mengalami kesulitan dalam menghubungkan permasalahan untuk diselesaikan apalagi dimasa pandemi saat ini, banyak siswa yang mengeluhkan kesulitan karena sering tidak mengerti bagaimana penyelesaian soal karena sistem pembelajaran yang tidak tatap muka, sehingga jika beberapa siswa mengalami kesulitan dalam menyelesaikan soal matematika yang diberikan guru maka siswa diperbolehkan bertanya langsung pada guru ke sekolah atau lewat Jalur Pribadi menggunakan aplikasi WhatsApp dan banyak juga siswa tidak peduli terhadap bagaimana cara penyelesaian soal, sehingga banyak siswa salah dalam membuat penyelesaian soal.

Minat adalah suatu rasa lebih suka dan rasa ketertarikan pada suatu hal atau aktivitas, tanpa ada yang menyuruh. Seorang siswa yang menaruh minat besar terhadap suatu pelajaran, ia pasti akan berusaha untuk memiliki nilai yang bagus. Untuk mencapai nilai yang bagus diperlukan daya nalar siswa yang baik dalam menyelesaikan soal-soal matematika. Dalam proses pembelajaran minat dan penalaran dapat mempengaruhi kualitas pencapaian hasil belajar siswa, sehingga semakin besar minat atau dorongan dari dalam diri siswa yang menimbulkan keterikatan dan pemusatan perhatian yang besar, tanpa ada paksaan akan mendatangkan kepuasan dalam dirinya serta dapat mencapai hasil belajar yang baik. 
ISSN. 2621-9832

JURNAL MathEdu (Mathematic Education Journal) http://journal.ipts.ac.id/index.php/MathEdu

Minat belajar siswa sangat menentukan keberhasilannya dalam proses belajar. Menurut Purwanto (dalam Marleni 2016:151), faktor-faktor yang mempengaruhi minat belajar menjadi dua, yaitu faktor internal dan faktor eksternal. Salah satu faktor internal yang mempengaruhi minat belajar siswa, faktor internal tersebut antara lain : perhatian siswa muncul didorong rasa ingin tahu. "Oleh karena itu rasa ini perlu mendapat rangsangan sehingga siswa selalu memberikan perhatian terhadap materi pelajaran yang diberikan", Sugihartono (dalam Marleni 2016:151). Sedangkan faktor eksternal yang mempengaruhi minat belajar adalah faktor sekolah dan faktor keluarga.

Untuk itu dalam pembelajaran matematika diperlukan cara yang dapat mengembangkan penalaran siswa dan menumbuhkan minat belajar siswa, ini diharapkan dapat menciptakan siswa sebagai penerus bangsa yang dapat menguasai matematika dengan baik dan akhirnya nanti mereka dapat menerapkan matematika dalam kehidupan sehari-hari dan untuk mengurangi lemahnya kemampuan penalaran dalam pembelajaran matematika, siswa perlu dibiasakan untuk memberikan argumen atas setiap jawabannya serta memberikan tanggapan atas jawaban yang diberikan oleh orang lain, sehingga apa yang sedang dipelajari menjadi lebih bermakna baginya. Maka oleh karena itu kemampuan penalaran matematis siswa selama pandemi covid-19 ditinjau dari minat belajar siswa perlu dianalisis.

\section{METODE PENELITIAN}

Jenis penelitian yang digunakan oleh peneliti yaitu metode penelitian deskriptif kualitatif. Menurut Sugiyono (dalam Lestari 2015), Penelitian kualitatif adalah penelitian yang berlandaskan pada filsafat post positivisme, digunakan untuk meneliti pada kondisi objek yang alamiah, dimana peneliti adalah sebaga instrumen kunci, pengambilan sumber data dilakukan secara purposive dan snowball, teknik pengumpulan data dengan triangulasi (gabungan), analisis data bersifat induktif/kualitatif, dan hasil penelitian kualitatif lebih menekankan makna daripada generalisasi.

Objek penelitian merupakan sesuatu yang menjadi perhatian dalam sebuah penelitian karena objek penelitian merupakan sasaran yang hendak dicapai untuk mendapatkan jawaban maupun solusi dari permasalahan yang terjadi. Objek penelitian ini adalah kemampuan penalaran siswa dan minat belajar siswa. Adapun Informan penelitian ini adalah beberapa guru bidang studi matematika dan siswa kelas VIII-3 SMP Negeri 5 Padangsidimpuan. Dalam Penelitian kualitatif, pengumpulan data dilakukan alamiah. Pada penelitian ini, peneliti menggunakan teknik pengumpulan data dengan angket tertutup, wawancara tak berstruktur, tes kemampuan penalaran dan dokumentasi.

Dalam penelitian diberikan tes kepada siswa untuk mengetahui sejauh mana pemahaman siswa terhadap materi pembelajaran dan kemampuan penalaran siswa. Tes diberikan kepada siswa kelas VIII-3 SMP Negeri 5 Padangsidimpuan dimana setiap tes terdiri dari 4 soal uraian. Kisi-kisi tes kemampuan penalaran matematis siswa dapat dilihat pada tabel berikut :

Tabel 1.Kisi-kisi Tes Kemampuan Penalaran Matematis Siswa

\begin{tabular}{|c|c|c|c|}
\hline No & Indikator & Nomor Soal & Banyak Soal \\
\hline 1 & $\begin{array}{l}\text { Menyajikan pernyataan } \\
\text { matematika melalui lisan, } \\
\text { tulisan,gambar, } \\
\text { atau diagram }\end{array}$ & \multirow{4}{*}{$1,2,3,4$} & \multirow{4}{*}{4} \\
\hline 2 & $\begin{array}{l}\text { MelakukanManipulasi } \\
\text { Matematika }\end{array}$ & & \\
\hline 3 & $\begin{array}{l}\text { Menyusun bukti, memberi } \\
\text { terhadap kebenaran solusi }\end{array}$ & & \\
\hline 4 & Menarik kesimpulan & & \\
\hline & Jumlah & & 4 \\
\hline
\end{tabular}


ISSN. 2621-9832

JURNAL MathEdu (Mathematic Education Journal) http://journal.ipts.ac.id/index.php/MathEdu

Adapun rubrik penilaian yang digunakan untuk menilai kemampuan penalaran siswa dapat dilihat pada tabel berikut :

Tabel 2.Rubrik Penilaian Kemampuan Penalaran Matematis Siswa

\begin{tabular}{l}
\hline Indikator \\
\hline 1. $\begin{array}{c}\text { Menyajikan pernyataan } \\
\text { matematika secara lisan, } \\
\text { tulisan, gambar dan } \\
\text { diagram }\end{array}$
\end{tabular}

Aspek yang diamati

Skor

Siswa tidak dapat menyajikan pernyataan matematika secara lisan, tulisan, gambar atau diagram

Siswa hanya sebagian kecil dapat menyajikan pernyataan matematika secara lisan, tulisan,

gambar, atau diagram

Siswa dapat memahami dan

dapat menyajikan pernyataan

matematika secara lisan, tulisan,

gambar, atau diagram

Siswa dapat menyajikan matematika secara lisan, tulisan, gambar, atau diagram dengan lengkap dan benar

Siswa tidak dapat melakukan manipulasi matematika 0

Siswa hanya sebagian kecil dapat

2. Melakukan Manipulasi melakukan manipulasi matematika Matematika

Siswa dapat melakukan manipulasi matematika dengan benar namun belum lengkap

Siswa dapat melakukan manipulasi matematika dengan benar dan lengkap

Siswa tidak dapat menyusun bukti, memberi alasan/bukti terhadap kebenaran solusi

Siswa hanya sebagian kecil dapat menyusun bukti, memberi

3. Menyusun bukti, memberi alasan/bukti terhadap kebenaran alasan/bukti terhadap kebenaran solusi solusi

Siswa dapat menyusun bukti, memberi alasan/bukti terhadap kebenaran solusi dengan benar namun belum lengkap

Siswa dapat menyusun bukti, memberi alasan/bukti terhadap kebenaran solusi dengan benar dan lengkap

1

1

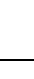

2

.


ISSN. 2621-9832

JURNAL MathEdu (Mathematic Education Journal) http://journal.ipts.ac.id/index.php/MathEdu

Vol. 4 No. 2 Juli 2021

Siswa dapat menarik kesimpulan

dengan lengkap dan benar

Endang Sri Rejeki (2019)

Cara menghitung hasil kriteria kemampuan penalaran matematis siswa berdasarkan skor tes adalah sebagai berikut:

$$
\mathrm{P}=\frac{f}{n} \times 100 \%
$$

Keterangan:

P : Persentase

f : : Frekuensi jawaban siswa

n : Jumlah skor keseluruhan (skor maksimum)

Berdasarkan hasil tes yang dikerjakan oleh siswa, setiap indikatornya diberi skor. Setelah diperoleh skor tes kemampuan penalaran matematis siswa, peneliti menentukan kategori skor yang diperoleh siswa. Kriteria kemampuan penalaran matematis siswa berdasarkan skor dapat dilihat pada tabel berikut :

Tabel 3. Kriteria Kemampuan Penalaran Matematis Siswa Berdasarkan Skor Tes

\begin{tabular}{cll}
\hline $\begin{array}{l}\text { Pencapaian Kemampuan Penalaran } \\
\text { Matematis Siswa }\end{array}$ & Kategori & \\
\hline$>70 \%$ & Tinggi & \\
\hline $55 \% \geq 70 \%$ & Sedang & \\
\hline$\leq 55 \%$ & Rendah & \\
\hline & & Tri Roro (2018)
\end{tabular}

Selanjutnya peneliti memberikan angket kepada siswa, dalam penelitian ini peneliti menggunakan angket tetutup sebagai teknik pengumpulan data untuk mendapatkan minat belajar siswa dikaitkan dengan kemampuan penalaran matematis siswa di SMP Negeri 5 Padangsidimpuan. Kisi-kisi angket dan penskoran minat belajar siswa dapat dilihat pada tabel berikut :

Tabel 4. Kisi-Kisi Angket Minat Belajar Siswa

\begin{tabular}{|c|c|c|c|}
\hline Indikator & Keterangan & Item soal & Jumlah soal \\
\hline \multirow[t]{3}{*}{ Perasaan senang } & $\begin{array}{l}\text { Pendapat siswa tentang } \\
\text { pembelajaran matematika }\end{array}$ & \multirow{3}{*}{$1,3,5$} & \multirow{3}{*}{3} \\
\hline & $\begin{array}{l}\text { Kesan siswa terhadap guru } \\
\text { matematika }\end{array}$ & & \\
\hline & $\begin{array}{l}\text { Perasaan siswa selama } \\
\text { mengikuti pembelajaran } \\
\text { matematika }\end{array}$ & & \\
\hline \multirow[t]{2}{*}{$\begin{array}{l}\text { Ketertarikan untuk } \\
\text { belajar }\end{array}$} & $\begin{array}{l}\text { Rasa ingin tahu siswa saat } \\
\text { mengikuti pembelajaran } \\
\text { matematika }\end{array}$ & \multirow{2}{*}{$8,10,13,15$} & \multirow[t]{2}{*}{4} \\
\hline & $\begin{array}{l}\text { Penerimaan siswa saat } \\
\text { diberikan tugas/PR oleh guru }\end{array}$ & & \\
\hline \multirow{2}{*}{$\begin{array}{l}\text { Menunjukkan } \\
\text { perhatian saat } \\
\text { belajar }\end{array}$} & $\begin{array}{l}\text { Perhatian saat mengikuti } \\
\text { pembelajaran matematika }\end{array}$ & \multirow[t]{2}{*}{$2,4,6,7$} & \multirow[t]{2}{*}{4} \\
\hline & $\begin{array}{l}\text { Perhatian siswa saat diskusi } \\
\text { pelajaran matematika }\end{array}$ & & \\
\hline \multirow[t]{2}{*}{$\begin{array}{l}\text { Keterlibatan dalam } \\
\text { belajar }\end{array}$} & $\begin{array}{l}\text { Kesadaran tentang belajar di } \\
\text { rumah }\end{array}$ & \multirow[t]{2}{*}{$9,11,12,14$} & \multirow[t]{2}{*}{4} \\
\hline & $\begin{array}{l}\text { Kegiatan siswa setelah dan } \\
\text { sebelum masuk sekolah }\end{array}$ & & \\
\hline
\end{tabular}


ISSN. 2621-9832

JURNAL MathEdu (Mathematic Education Journal) http://journal.ipts.ac.id/index.php/MathEdu

Vol. 4 No. 2 Juli 2021

Jumlah keseluruhan

Tabel 5. Penskoran Hasil Angket

\begin{tabular}{llc}
\hline Skor & Alternatif Jawaban & Nomor It em \\
\hline 4 & Sangat Setuju (SS) & \multirow{2}{1}{$, 2,3,4,5,6,7,8,9,10$} \\
\cline { 1 - 2 } & Setuju (S) & $, 11,12,13,14,15$ \\
\cline { 1 - 2 } 1 & Tidak Setuju (TS) & \\
\hline \multicolumn{2}{l}{ Sangat Tidak Setuju (STS) } & Arikunto (Rambe, Nelli 2020:32)
\end{tabular}

Hasil angket mengenai minat belajar siswa dapat dihitung dengan menggunakan rumus :

Keterangan:

$$
\mathrm{P}=\frac{f}{n} \times 100 \%
$$

$\mathrm{P} \quad$ : Presentase

f : Frekuensi jawaban siswa

$\mathrm{n} \quad$ : Jumlah skor keseluruhan (skor maksimum)

Skor angket mengenai minat belajar siswa yang diperoleh selanjutnya dikualifikasikan dengan ketentuan sebagaimana tertera pada tabel berikut:

Tabel 6.Persentase Skor Angket Minat Belajar Siswa

\begin{tabular}{cc}
\hline Persentase skor yang diperoleh & Kategori \\
\hline $\mathrm{P} \geq 66 \%$ & Tinggi \\
\hline $33 \% \leq \mathrm{P} \leq 66 \%$ & Sedang \\
\hline $\mathrm{P} \leq 33 \%$ & Rendah \\
\hline & Afif Abror $(2014: 22)$
\end{tabular}

Keabsahan data dilakukan untuk membuktikan apakah penelitian yang dilakukan benar-benar merupakan penelitian ilmiah sekaligus untuk menguji data yang diperoleh. "Teknik pemeriksaan keabsahan atau validitas data pada dasarnya merupakan teknik yang harus ditempuh untuk menunjukkan bahwa data yang terkumpul benar-benar terdapat secara alami dan umum", (Nugrahani 2014:213). Uji keabsahan data pada penelitian kualitatif dengan menggunakan triangulasi akan lebih meningkatkan kekuatan data apabila dibandingkan dengan satu pendekatan.

Analisis data adalah proses mencari dan menyusun secara sistematis data yang diperoleh dari hasil wawancara, catatan lapangan, dan bahan-bahan lain, sehingga dapat mudah dipahami, dan temuannya dapat diinformasikan kepada orang lain. Selanjutnya Nasution (dalam Sugiyono 2013:244) menyatakan bahwa, "Melakukan analisis adalah pekerjaan yang sulit, memerlukan kerja keras. Analisis memerlukan daya kreatif serta kemampuan intelektual yang tinggi". Adapun proses analisis data penelitian adalah sebelum dilapangan dan analisis selama dilapangan model Miles dan Huberman. Aktivitas dalam menganalisis data yaitu :

\section{a. Data Reduction (Reduksi Data)}

Mereduksi data berarti "merangkum, memilih hal-hal yang pokok, memfokuskan pada hal-hal yang penting, mencari tema dan polanya dan membuang yang tidak perlu. Dalam tahap reduksi, peneliti mengumpulkan, merangkum, dan mengelompokkan data kemampuan penalaran matematis siswa yang berasal dari data tes, dokumentasi, dan wawancara.

\section{b. Data Display (Penyajian Data)}

Setelah data direduksi, maka langkah selanjutnya adalah mendisplaykan data atau menyajian data. Dalam tahap ini, peneliti menyajikan hasil pekerjaan siswa, menyajikan hasil wawancara dengan responden. Data yang disajikan berupa data skor kemampuan penalaran matematis siswa. Disajikan juga hasil jawaban tes kemampuan penalaran matematis yang ditulis siswa dalam lembar jawaban. Selain itu, hasil wawancara juga disajikan dalam bentuk tanya-jawab yang dilakukan oleh peneliti dengan guru dan 
siswa.

\section{c. Conclusion Drawing /Verification (Penarikan Kesimpulan)}

Data yang diperoleh di lapangan baik secara dokumentasi, wawancara maupun tes akan dianalisis secara cermat dan akurat, sehingga penarikan kesimpulan dari hasil penelitian dapat menjawab rumusan masalah yang ditentukan.

\section{HASIL DAN PEMBAHASAN}

Pelaksanaan tes dilakukan pada siswa kelas VIII-3 SMP Negeri 5 Padangsidimpuan dengan 10 sampel subyek pada tanggal 9 Maret 2020 di kelas VIII-3 SMP Negeri 5 Padangsidimpuan dengan informan sebanyak 10 orang siswa SMP. Dalam pelaksanaan penelitian, materi yang digunakan dalam tes adalah materi Luas dan keliling Lingkaran yang disajikan dalam bentuk uraian. Kemudian dilanjutkan dengan pelaksanaan wawancara pada saat itu juga setelah mengerjakan soal tersebut. Peneliti mengambil 4 siswa untuk melaksanakan kegiatan wawancara yaitu 1 siswa yang mewakili siswa yang berkemampuan tinggi, 1 siswa yang mewakili siswa yang berkemampuan sedang, dan 2 siswa yang mewakili siswa yang berkemampuan rendah. Hasil Rekap nilai dan jawaban tes kemampuan penalaran dapat dilihat pada tabel berikut :

Tabel 7.Rekap data hasil dari tes kemampuan penalaran siswa kelas VIII-3 SMP Negeri 5 Padangsidimpuan

\begin{tabular}{llccc}
\hline No & Inisial & \multicolumn{2}{c}{ Kategori } \\
\cline { 2 - 4 } & & Tinggi & Sedang & Rendah \\
\hline 1 & FTF & $\checkmark$ & & \\
\hline 2 & APS & $\checkmark$ & $\checkmark$ & \\
\hline 3 & LRI & & $\checkmark$ & $\checkmark$ \\
\hline 4 & BLR & & $\checkmark$ \\
\hline 5 & AT & & $\checkmark$ \\
\hline 6 & FPW & $\checkmark$ \\
\hline 7 & EPS & $\checkmark$ \\
\hline 8 & ARS & & $\checkmark$ \\
\hline 9 & JFH & & $\checkmark$ \\
\hline 10 & RA & & \\
\hline
\end{tabular}

Tabel 8. Rekap nilai hasil dari jawaban tes kemampuan penalaran siswa kelas VIII-3 SMP Negeri 5 Padangsidimpuan

\begin{tabular}{lcccc}
\hline No & Inisial & Skor & Persentase Nilai & Kategori \\
\hline 1. & FTF & 40 & $83 \%$ & Tinggi \\
\hline 2. & APS & 39 & $81 \%$ & Tinggi \\
\hline 3. & LRI & 32 & $67 \%$ & Sedang \\
\hline 4. & BLR & 33 & $69 \%$ & Sedang \\
\hline 5. & AT & 10 & $21 \%$ & Rendah \\
\hline 6. & FPW & 8 & $17 \%$ & Rendah \\
\hline 7. & EPS & 2 & $4 \%$ & Rendah \\
\hline $8 \mathbf{T}$ & ARS & 16 & $33 \%$ & Rendah \\
\hline $9 \mathbf{a}$ & JFH & 26 & $54 \%$ & Rendah \\
\hline 1 B. & RA & 17 & $35 \%$ & Rendah \\
\hline
\end{tabular}


TabeL 9. Persentase hasil keseluruhan jawaban yang diperoleh dari pemberian tes penalaran matematis siswa kelas VIII-3 SMP Negeri 5 Padangsidimpuan

\begin{tabular}{ccccc}
\hline No & Persentase skor yang diperoleh & Kategori & Jumlah Informan & f/n x 100\% \\
\hline 1 & $>70 \%$ & Tinggi & 2 & $20 \%$ \\
\hline 2 & $55 \% \geq 70 \%$ & Sedang & 2 & $20 \%$ \\
\hline 3 & $<55 \%$ & Rendah & 6 & $60 \%$ \\
\hline & Jumlah & & 10 & $100 \%$ \\
\hline
\end{tabular}

Persentase hasil tes kemampuan penalaran matematis siswa SMP kelas VIII-3 Negeri 5 Padangsidimpuan yang didapatkan yaitu kemampuan tinggi $20 \%$ yang berjumlah 2 orang siswa, kemampuan sedang $20 \%$ dengan jumlah 2 orang siswa, dan kemampuan rendah $60 \%$ dengan jumlah 6 orang siswa. Sehingga dapat disimpulkan bahwa kemampuan penalaran matematis siswa kelas VIII-3 SMP Negeri 5 Padangsidimpuan masih rendah.

Hasil penelitian yang telah dianalisis peneliti ditemukan bahwa siswa yang memiliki kemampuan tinggi, siswa dapat menjelaskan apa yang diketahui , apa yang ditanyakan. Siswa juga mampu memahami rumus apa yang dibutuhkan dan pengetahuan apa yang dibutuhkan untuk menyelesaikan permasalahan ini. Siswa juga dapat memberikan alasan/bukti terhadap jawaban yang diberikan dan dapat menarik kesimpulan. Hal ini menunjukkan bahwa siswa telah memenuhi indikator penalaran matematis.

Hasil penelitian pada siswa berkemampuan sedang, siswa mampu menuliskan apa yang diketahui dan apa yang ditanyakan pada soal. Siswa juga mampu menuliskan rumusrumusnya untuk menyelesaikan soal.

Hasil penelitian pada siswa berkemampuan rendah, kemampuan siswa rendah dalam melakukan manipulasi matematika, memberi bukti, dan menarik kesimpulan. Berbeda dengan hasil penelitian yang dilakukan oleh Ahmad Fadillah (2019) dengan judul "Analisis Kemampuan Penalaran Deduktif Matematis Siswa" dengan kesimpulan kemampuan penalaran deduktif SMA muhammadiyah 02 Cipondoh Tangerang memiliki kemampuan tinggi sekitar 12,82\%, sedangkan kemampuan sedang mencapai $71,8 \%$ dan kemampuan rendah mencapai $15,38 \%$.

Hal ini bisa terjadi karena kemampuan penalaran matematis siswa dipengaruhi oleh beberapa faktor. Menurut Yuniawati (2017) Salah satu faktor yang mempengaruhi kemampuan penalaran siswa adalah kemampuan awal siswa. Sedangkan menurut Quratul (2020), "Tinggi rendahnya kemampuan penalaran matematis siswa dipengaruhi oleh faktor eksternal dan internal. Faktor eksternal adalah faktor yang ada di luar individu siswa seperti keluarga, keadaan rumah, guru. faktor internal adalah faktor yang ada dalam diri individu siswa, seperti kematangan dan pertumbuhan".

Selanjutnya dilakukan penyebaran angket pada tanggal 9 Maret 2020 di kelas VIII-3 SMP Negeri 5 Padangsidimpuan dengan informan sebanyak 10 orang siswa SMP. Dibawah ini hasil rekap data dan nilai angket angket nama-nama siswa yang merupakan subyek dalam penelitian :

Tabel 10. Rekap data hasil dari angket minat belajar siswa kelas VIII-3 SMP Negeri 5 Padangsidimpuan

\begin{tabular}{llccc}
\hline No & Inisial & \multicolumn{3}{c}{ Kategori } \\
\cline { 3 - 5 } & & Tinggi & Sedang & Rendah \\
\hline 1 & FTF & $\checkmark$ & & \\
\hline 2 & APS & $\checkmark$ & $\checkmark$ & \\
\hline 3 & LRI & & $\checkmark$ & $\checkmark$ \\
\hline 4 & BLR & & & $\checkmark$ \\
\hline 5 & AT & & & \\
\hline 6 & FPW & & & \\
\hline
\end{tabular}


ISSN. 2621-9832

JURNAL MathEdu (Mathematic Education Journal) http://journal.ipts.ac.id/index.php/MathEdu Vol. 4 No. 2 Juli 2021

\begin{tabular}{llc}
\hline 7 & EPS & $\checkmark$ \\
\hline 8 & ARS & $\checkmark$ \\
\hline 9 & JFH & $\checkmark$ \\
\hline 10 & RA & $\checkmark$ \\
\hline
\end{tabular}

Tabel 11. Rekap nilai hasil dari angket minat belajar siswa kelas VIII-3 SMP Negeri 5 Padangsidimpuan

\begin{tabular}{lcccc}
\hline No & Inisial & Skor & Persentase Nilai & Kategori Minat \\
\hline $1 . \mathbf{a}$ & FTF & 45 & $75 \%$ & Tinggi \\
\hline $2 . \mathbf{b}$ & APS & 50 & $83 \%$ & Tinggi \\
\hline $3 \cdot \mathbf{e}$ & LRI & 35 & $58 \%$ & Sedang \\
\hline $4 . \mathbf{1}$ & BLR & 39 & $65 \%$ & Sedang \\
\hline 5. & AT & 18 & $30 \%$ & Rendah \\
\hline $6 . \mathbf{1}$ & FPW & 19 & $32 \%$ & Rendah \\
\hline $7 . \mathbf{2}$ & EPS & 19 & $32 \%$ & Rendah \\
\hline $8 .$. & ARS & 19 & $32 \%$ & Rendah \\
\hline 9. & JFH & 20 & $33 \%$ & Rendah \\
\hline $10 \mathbf{P}$ & RA & 20 & $33 \%$ & Rendah \\
\hline $\mathbf{e}$ & & & &
\end{tabular}

Tabel 12. Persentase hasil keseluruhan jawaban yang diperoleh dari penyebaran angket tentang minat belajar siswa kelas VIII-3 SMP Negeri 5 Padangsidimpuan

\begin{tabular}{ccccc}
\hline No & Persentase skor yang diperoleh & Kategori & Jumlah Informan & f/n x 100\% \\
\hline 1 & $\mathrm{P} \geq 66 \%$ & Tinggi & 2 & $20 \%$ \\
\hline 2 & $33 \% \leq \mathrm{P} \leq 66 \%$ & Sedang & 2 & $20 \%$ \\
\hline 3 & $\mathrm{P} \leq 33 \%$ & Rendah & 6 & $60 \%$ \\
\hline & Jumlah & & 10 & $100 \%$ \\
\hline
\end{tabular}

Persentase hasil angket minat belajar siswa SMP kelas VIII-3 Negeri 5 Padangsidimpuan yang didapatkan yaitu kemampuan tinggi 20\% yang berjumlah 2 orang siswa, kemampuan sedang 20\% dengan jumlah 2 orang siswa, dan kemampuan rendah $60 \%$ dengan jumlah 6 orang siswa. Sehingga dapat disimpulkan bahwa minat belajar siswa kelas VIII-3 SMP Negeri 5 Padangsidimpuan masih rendah.

Hal ini jika dikaitkan dengan hasil tes kemampuan penalaran yang diberikan sebelumnya bahwa siswa kelas VIII-3 SMP Negeri 5 Padangsidimpuan menunjukkan kemampuan penalaran masih rendah, ini dapat terjadi karena siswa tidak memiliki minat dalam belajar. Menurut Purwanto (dalam Marleni 2016:151), ada beberapa faktor-faktor yang mempengaruhi minat belajar, yaitu faktor internal dan faktor eksternal. Salah satu faktor internal yang mempengaruhi minat belajar siswa, faktor internal tersebut antara lain : perhatian siswa muncul didorong rasa ingin tahu . "Oleh karena itu rasa ini perlu mendapat rangsangan sehingga siswa selalu memberikan perhatian terhadap materi pelajaran yang diberikan", Sugihartono (dalam Marleni 2016:151). Sedangkan faktor eksternal yang mempengaruhi minat belajar adalah faktor sekolah dan faktor keluarga . Faktor dari dalam diri siswa yaitu perhatian yang didorong oleh rasa ingin tahu, dapat dilihat dari hasil wawancara yang dilakukan oleh peneliti bahwa kebanyakan siswa kelas VIII-3 merasa tidak senang terhadap pelajaran matematika, tidak memiliki ketertarikan dalam pembelajaran matematika hal itu membuat siswa tidak memiliki rasa ingin tahu sehingga saat diberikan tugas/ soal-soal siswa tidak mampu menyelesaikan dan tidak nalar terhadap soal-soal yang diberikan.

Siswa dengan minatnya tinggi selalu merasa senang terhadap pembelajaran matematika, memiliki ketertarikan untuk belajar, dan menunjukkan perhatiannya saat belajar dengan cara mendengarkan penjelasan guru saat menjelaskan materi walaupun situasi pandemi saat ini, siswa dengan minat yang tinggi tetap aktif dalam pembelajaran matematika hal itu dapat 
terbukti dengan hasil tes penalaran yang diberikan bahwa FTF mampu menyelesaikan dengan baik .

Sedangkan siswa dengan minat yang sedang, cenderung merasa senang terhadap pembelajaran mtematika apabila gurunya mengajar dengan menyenangkan dan melihat situasi/keadaan saat belajar, menunjukkan perhatiannya saat belajar dengan cara memperhatikan guru saat menjalaskan materi dan menyelesaikan tugas kepada guru apabila mengerti terhadap penjelasan guru karena LRI merasa mengalami kesulitan yaitu sering tidak mengerti terhadap materi yang diberikan guru karena situasi pandemi saat ini yang tidak memungkinkan untuk bertatap muka dan saat diberikan tes penalaran cukup mampu dalam menyelesaikan.

Siswa yang minatnya rendah, merasa tidak senang terhadap pembelajaran matematika walaupun gurunya mengajar dengan menyenangkan karena AT dan FPW merasa pelajaran matematika adalah pelajaran yang tidak disukai, dan cenderung tidak aktif dalam proses pembelajaran matematika, tidak menunjukkan perhatian saat belajar dan tes penalaran yang diberikan tidak dapat diselesaikan dengan baik.

Berbeda dengan hasil penelitian yang dilakukan oleh Suci Hidayat (2020) dengan judul "Analisis Kemampuan Penalaran Matematis Ditinjau dari Kemandirian Belajar dan Minat Belajar Pada Siswa kelas VIII SMP Negeri 2 Banyubiru Tahun Pelajaran 2019/2020", dengan kesimpulan siswa yang kemampuan penalaran matematis dengan tingkat kemandirian dan minat belajar yang tinggi berjumlah 2 siswa dan mampu memenuhi empat indikator penalaran. Sedangkan siswa yang kemampuan penalaran matematis dengan tingkat kemandirian dan minat belajar yang sedang berjumlah 5 orang dan mampu memenuhi 3 indikator, dan siswa yang kemampuan penalaran matematis dengan tingkat kemandirian dan minat belajar yang rendah berjumlah 3 orang dan tidak mampu memenuhi indikator. Maka disimpulkan bahwa kemampuan penalaran dengan tingkat kemandirian dn minat belajar kels VIII SMP Negeri 2 Banyubiru Kabupaten Semarang masuk dalam kategori sedang.

\section{KESIMPULAN}

Berdasarkan hasil penelitian dan pembahasan yang telah diuraikan, maka dapat diambil kesimpulan bahwa kemampuan penalaran matematis siswa kelas VIII-3 SMP Negeri 5 Padangsidimpuan pada materi luas dan keliling lingkaran pada masa pandemi ini termasuk dalam kategori rendah. Hal ini dapat dilihat dari banyaknya siswa yang memiliki kemampuan penalaran matematis dalam kategori rendah sebanyak $60 \%$, sedang 20\%, tinggi $20 \%$. Dan untuk hasil analisis angket minat belajar siswa kelas VIII-3 terhadap pembelajaran matematika dapat disimpulkan bahwa $60 \%$ siswa minatnya rendah dengan kemampuan penalaran nya rendah dikarenakan siswa tidak menyukai pelajaran matematika, $20 \%$ lagi minatnya sedang dengan kemampuan penalarannya sedang dikarenakan siswa menyukai pelajaran matematika apabila guru mengajar dengan menyenangkan, dan $20 \%$ lagi minatnya tinggi dengan kemampuan penalarannya tinggi dikarenakan siswa menyukai pelajaran matematika dan selalu tertantang dengan soal-soal matematika. Maka peneliti menyimpulkan bahwa minat belajar siswa dikaitkan dengan kemampuan penalaran siswa kelas VIII-3 SMP Negeri 5 Padangsidimpuan pada masa pandemi ini terbilang rendah, perlu adanya perbaikan agar siswa memiliki minat yang tinggi secara keseluruhan.

Dan jika dikaitkan dengan hasil tes penalaran yang diberikan kepada siswa kelas VIII-3 yang dikategorikan rendah, ini menunjukkan bahwa semakin rendah minat belajar siswa terhadap pembelajaran matematika maka semakin rendah juga penalaran siswa tersebut, karena pada umumnya jika siswa tidak berminat atau tidak suka terhadap pembelajaran matematika maka dalam menyelesaikan soal-soal matematika pun siswa tidak akan nalar. Maka dapat diambil kesimpulan bahwa rendahnya kemampuan penalaran matematis siswa disebabkan oleh faktor luar maupun faktor dari dalam diri seseorang, salah satu faktor dari dalam diri yaitu minat belajar.

\section{REFERENSI}

Fadillah, Ahmad. 2019. Analisis Kemampuan Penalaran Deduktif Matematis Siswa. Jurnal Teori dan Aplikasi Matematika. Vol. 3. No. 1. 
Harahap, Muhammad Syahril. 2017. Pengembangan Modul Pembelajaran Matematika Berbasis Web. Jurnal Education and Development. Vol. 4, No. 5. Hal. 14

Hidayat, Suci. 2020. Analisis Kemampuan Penalaran Matematis Ditinjau dari Kemandirian Belajar dan Minat Belajar Pada Siswa kelas VIII SMP Negeri 2 Banyubiru Tahun Pelajaran 2019/2020.

Konita, Mita.2019. Kemampuan Penalaran Matematis dalam Model Pembelajaran Connecting, Organizing, Reflecting, Extending (CORE). ISSN 2613-9189. Hal. 612

Lestari, Karunia Eka. 2015. Penelitian Pendidikan Matematika. Bandung. Reflika Aditama

Marleni, Lusi. 2016. Faktor-Faktor Yang Mempengaruhi Minat Belajar Siswa Kelas VIII SMP Negeri 1 Bangkinang. Journal Cendekia: Jurnal Pendidikan Matematik. Vol. 1. No. 1

Mukhlas, Afif Abror. 2014. Upaya Meningkatkan Minat Dan Hasil Belajar Siswa Dengan Menggunakan Metode Mind Map Pada Materi Bangun Ruang Kelas V MI Yappi Gedad 2 Playen Gunungkidul

Nugrahani, Farida. 2014. Metode Penelitian Kualitatif. Surakarta.

Quratul, Lia. 2020. Analisis Kemampuan Penalaran Matematis Siswa Ditinjau Dari SelfEfficacy Siswa SMP Kelas VII. Jurnal Edumath. Vol. 6. No. 1

Rambe, Nelli.2020. Peningkatan Kemampuan Penalaran Matematis Siswa Melalui Penggunaan Model Problem Posing di SMP Swasta Tapian Nauli. Jurnal MathEdu.Vol. 3, No. 2

Rejeki, Endang Sri. 2019. Penerapan Model Pembelajaran Kooperatif Tipe Pair Checks Untuk Meningkatkan Kemampuan Penalaran Matematis Siswa di SMA Negeri 1 Sibabangun. Jurnal MathEdu. Vol.1, No.1. Maret 2018

Suprihatin, Tri Roro. 2018. Analisis Kemampuan Penalaran Matematis Siswa SMP Pada Materi Segitiga dan Segiempat. Jurnal Kajian Pembelajaran Matematika. Vol. 2. No. 1 . Hal 10

Yuniawati, Tutut. 2017. Analisis Kemampuan Penalaran Matematis Siswa Dalam Menyelesaikan Soal cerita Pada Materi Perbandingan Berdasarkan Kemampuan Awal Matematika. Vol. 01. No. 01 